\title{
On Hemingway's Ecological Ethic in The Old Man and the Sea
}

\section{Zhiqiang Zhang}

Shandong University of Technology, Zibo 255000, China

\begin{abstract}
Ernest Hemingway, a famous American writer and Nobel Prize winner, is a great writer with deep ecological ethic. With the perspective of modern scientific ecological view, this paper try to prove that Hemingway embodied his strong ecological ethic in his famous work The Old Man and the Sea by analyzing the description of the old man Santiago's simple life, the beauty of sea, Santiago's unity with all the sea creatures and the love and respect of the sea creatures. It also points out that The Old Man and the Sea reflects Hemingway's awareness of ecological protection.
\end{abstract}

Keywords - Hemingway; Santiago; Eco-ethic.

\section{INTRODUCTION}

Ernest Hemingway is one of the most celebrated and remarkable writers in the world literature. His works have attracted numerous readers, and a great many researchers all over the world have spent much academic energy on them from different perspectives. Nevertheless, very few critics have associated Hemingway's works with the newly developed ecological criticis $\mathrm{m}$. With the hope of enriching the research of the great literature and further arousing people's ecological awareness, this paper employs modern scientific ecological view to explore the abstract ecological ethic in Hemingway's famous work The Old and the Sea.

Modern scientific ecological view includes many different theories, among which, the central and most important theory is ecological holis $\mathrm{m}$, ecological holism proposes that we should focus attention on the whole ecological system and everything should be judged by the interests of the whole system instead of some parts, the theory is based upon the philosophical position that wholes cannot be taken apart and that every apparent whole can be understood only in the context of the larger whole containing it. This belief is epitomized in the statement that a whole is more than the sum of its parts.

Ecological holists believe that "all species are created equally, each one of them has rights to live, grow, and pursue happiness in their own style"(Nelson,2000); "every species has its position in the ecological system, and no one is higher than the others and has the right to control others"(Mckusick,2000).Nature is like an organism, in which various parts of nature are closely interdependent and densely woven into a single web of being. Everything is related with everything else, as in the human body.

However, it doesn't mean we should totally deny man's rights and pay attention solely on the whole ecological system; man can live as happily as before, what ecological holism emphasize is putting human beings' desire under control, making sure that human activities don't disturb nature's ecological equilibrium. This limitation puts the interests of ecological system before man, because man is just a part of the whole system, man cannot live alone without ecological system, and the end of the systemmeans the end of human beings.

\section{THE ECOLOGICAL ETHIC IN THE OLD MAN AND THE SEA}

Ernest Hemingway, a famous American writer and Nobel Prize winner, is a great writer with deep ecological ethic. His representative work The Old Man and the Sea, chronicles the simple story of how Santiago, an old Cuban fisherman, fights bravely for three consecutive days with a giant marlin and later a group of cruel sharks in the sea. The plot of the story is quite simple with the 
main content focused on three days' activities of the old man. The main activities are the epic struggle between the old man and a big fish, and the fight between the old man and the sharks. The old Cuban fisherman Santiago has been unable to catch a fish for eighty-four days. Later he is convinced that he will begin to catch fish again and that he is just going through an unlucky time. Believing that his luck will change, he takes his skiff out much further into the sea than usual, thinking if he goes into deep waters, he will catch a fish. He ventures far into the Gulf Stream. At noon, a big fish, which Santiago knows to be a marlin, takes the bait at 100 fathoms. The old man expertly hooks the fish, but cannot pull it up. Instead, the boat is pulled by the fish. In the following two days and nights, Santiago perseveres to hold onto the fishing line that cuts into his hands and causes great pain. His back is also strained and bent, and his shoulders are exhausted. During the struggle with the fish, Santiago feels a deep sympathy and admiration for the marlin. On the third day the fish is tired and Santiago manages to kill the fish. But in the following day, sharks attracted by the blood, inevitably appear. The old man fights the sharks off as best as he can. However, the sharks devour the marlin at last, leaving the only skeleton of the fish. Totally exhausted, Santiago gets back to his home, collapses on his bed and had a dream. The classic novelette became an instant success and immediately soared to the top of the best-seller list and remained there for a long time of six months after it was published. The work was awarded the Pulitzer Prize in 1953.

2.1 The Old Man and the Sea is such a work. Set the novella primarily on the coast of Havana, Cuba, Hemingway repeatedly demonstrates his ecological ethic through his protagonist - a very old Cuban fisherman. Santiago, one of the most memorable characters in Hemingway's canon, is an eccentric fisherman who lives remote from the cultural city. Santiago nearly serves as a hermit in the fishing village. The old man's shack is a good example: one room, a table, a chair, a bed, and a place on the dirt floor to cook with charcoal. The old man eats raw fish, drinks seawater on occasion, and lives in the shack. He goes barefooted, sleeps on old newspapers and wears heavily patched clothes. This description tells us that he is poor certainly. But Santiago is content with the simplicity imposed by his poverty, because he is himself a simple person making few demands of life or other people. Yet we hear no complaint at any time from Santiago and no suggestion that he is unhappy. All these details express Santiago's contentment with the simple life and his feeling of returning to nature. The old man Santiago's contentment also reveals that he is spiritual richer than a man who retires with a wealthy savings account and a suburban home filled with gadgets and appliances. In fact, a sense of happiness lies in how you look at your life not what you possess. A man who walks barefoot, who eats raw fish, who suffers pain, and who does penance, is the most obvious spokesman for Hemingway's ecological ethic. Santiago reveres animals though he at times has to kill some of them. In doing so, he lives one of the central creeds of deep ecology.

The harmonious relationship between man and nature is reflected in The Old Man and the Sea through the vivid description on its beauty and Santiago's unity with all the sea creatures. The old man has a sweet dream at the night before he sets out to the sea. He dreams of the ancient Africa with beautiful beaches, mountains and lions. The writer here first described the old man's harmonious relationship with nature through the depiction, such as "He was asleep in a short time and he dreamed of Africa when he was a boy and the long golden beaches and the white beaches, so white they hurt your eyes, and the high capes and the great brown mountains. He lived along that coast now every night, and in his dream he heard the surf roar and saw the native boats come riding through it. He smelled the tar and oakum of the deck as he slept and he smelled the smell of Africa that the land breeze brought at morning" (Wu,2009). By reading this paragraph, we can see that everything in his dream is filled with beauty, energy and vitality. And Santiago' harmonious relationship with nature can be also detected through some of the picturesque descriptions when Santiago gets to the sea. In this beautiful and harmonious world made up of the sea and the sky, the old man takes advantage of his gifts to have a dialogue with everything including the sun, the moon and the stars above the sea. In the day, the sun became his guide and gave him time and space concept. For instance: "The sun was two hours higher now and it did not hurt his eyes so much to look into the 
east." He looked up at the sun carefully, "It is not much more than noon" (Wu,2009). During the night, the moon and the stars he knew succeeded to become his leaders and tell him the directions and some other information. For example: "The sky was clouding over to the east and one after another the stars he knew were gone. It looked as though he was moving into a great canyon of clouds and the wind had dropped. There will be a bad weather in three or four days" (Wu,2009).

As the story goes by, there are more and more descriptions of the sea, from which we can immediately feel its beauty and tranquility. And through Hemingway's writing, we can sense his great love for the sea, which is the representation of the nature..."The sun rose thinly from the sea and the old man could see the other boars, low on the water and well in toward the shore, spread out across the current. Then the sun was brighter and the glare came on the water then, as it rose clear, the flat sea sent it back at his eyes so that it hurt sharply and he rowed without looking into it" (Wu,2009).

At the end of The Old Man and the Sea, there is a vision in Santiago's final dream, in which he sees the lions play like young cats on the beach. It shows that the peaceful picture means man and nature finally reach harmony. Conflicts vanish, nature gets respected, and man no longer feels guilty for killing. Everything is perfect.

2.2 Santiago looks at the ocean with love and respect. In his eyes, the sea is just like a gentle female that is beautiful and elegant. The old man always thought of her as feminine and as something that gave or withheld great favors. And if she did wild or wicked things it was because she could not help them. Everything in the sea is also filled with beauty, energy and vitality, which can be also detected through one of the picturesque descriptions when Santiago gets to the sea: "The clouds over the land now rose like mountains and the coast was only a long green line with the gray blue hills behind it. The water was a dark blue now, so dark that it was almost purple. As he looked down into it he saw the red sifting of the plankton in the dark water and the strange light the sun made now...and nothing showed on the surface of the water but some patches of yellow, unbleached Sargasso weed and the purple, formalized, iridescent, gelatinous bladder of a Portuguese man-of-war floating close beside the boat"(Wu,2009). As we can see from above, there are many different kinds of color words in the description of the sea, which instantly attract our eyes and inspire readers' imagination of the beautiful sea. By adding luster to the novel with the colors of the sea, there appears a colorful picture unfolding before our eyes.

The old man has quite a sense of sorrow for the turtles, for "most people are heartless about turtles because a turtle's heart will beat for hours after he has been cut up and butchered" and "I have such a heart too and my feet and hands are like theirs"(Wu,2009). During the night he sees two porpoises coming around the boat and hears them rolling and blowing. For their beauty he highly praises, "They are good. They play and make jokes and love one another. They are our brothers like the fly ing fish" (Wu, 2009).

Apart from fish and turtles, the old man also loves the birds very much and there are many descriptions of his affection of birds. The old man believes that birds are human's friends and they are small and delicate, thus should be pitied and protected. From the following description of birds, we can deeply feel the old man's love and sympathy for birds: "He was sorry for the birds, especially the small delicate dark terns that were always flying and looking and almost never finding, and he thought, the birds have a harder life than we do except for the bobber birds and the heavy strong ones. Why did they make birds so dedicate and fine as those sea swallows when the ocean can be so cruel? She is very kind and very beautiful. But she can be so cruel and it comes so suddenly and such birds that fly, dipping and hunting, with their s mall sad voices are made too delicately for the sea" (Wu,2009).

In The Old Man and the Sea Santiago remarks his struggle with the Marlin suggests that there is a true equality between man and other forms of life. Santiago declares that the fish is not his enemy, but his brother. He believed that man and all the other living things are creatures at the same level of life. There are only differences in terms of shape, size, intelligence, but no differences in terms of advantage and superiority. Therefore, in the competition with the marlin, the old man could have such feeling: "You are killing me, fish, the old man thought. But you have a right to. Never have I seen a 
greater, or more beautiful or a calmer or more noble thing than you, brother. Come on and kill me. I don't care who kills who" (Wu,2009).

It is interesting that the old man doesn't seem a noble to care who kills who. This, like so much of Santiago's relation to the fish, recalls an aristocratic code honor in which dying by the hand of a noble opponent is as noble an end as defeating him. Instead of trying to degrade his opponent, Santiago elevates it, accepting with the equal proposition that his death is as worthy an outcome of the struggle as his opponent's death. He is only worthy to kill the opponent if he is worthy to be killed by him.

2.3 The Old Man and the Sea reflects Hemingway's awareness of ecological protection at the same time. The eighty-four days of continual failure and the old man's previous experience of eighty-seven days without a success are the warning and admonition from nature. But Santiago himself is so self-determined and self-centered that he always neglects the voice of nature. As an old and experienced fisherman, Santiago has killed a great many creatures in the sea, and the great nature has lost a lot of good companions because of his personal need and lust. On this point, the old man, who has been generally interpreted as a code hero, can actually be defined as a destroyer of the balance of natural order and is bound to receive severe punishment from the law of nature. The groups of sharks are abstractly meant to be the embodiment of the punishment from nature in front of which the old experienced fisherman and destroyer of nature is doomed to be defeated. The marlin is not able to escape from its doomed fate in the end. But its death also causes a disastrous ending to the old man. The appearance of the sharks is obviously brought out directly by the old man's killing of the great fish. In the book, Santiago himself also regrets that "I wish it were a dream and that I had never hooked him. I'm sorry about it, fish. It makes everything wrong" ... "I shouldn't have gone out so far"... (Wu,2009).I have killed too many fishes and have in some way destroyed the order of nature. Only when we keep the balance of the system can we make sure both man and nature live in peace together.

\section{CONCLUSION}

The Old Man and the Sea, Hemingway's presentation of fishing story offers his ecological concern for the relationship between man and nature. In his view, man's relation to nature is to participate in and respect for natures, rather than control of, dominate over, and alienate from it. With the description of Santiago's integration with the sea and the sea creatures, Hemingway gave the readers a beautiful picture of the fascination of the great nature. Through the old fisherman's motive of getting out to the sea for fishing, Hemingway stressed human beings' dependence on the natural world. With the tragic ending of the old man's final defeat by the sharks, the great writer skillfully showed the great power of nature and the doomed failure of the destroyer of natural balance. The quality between human and the sea creatures demonstrated in The Old Man and the Sea also indicates that "human is not superior to other creations but a part of the intricate web of life" (Simons,2002). In respecting nature, human can live in harmony with the nonhuman. Hemingway is a writer with ecological ethic and his ideas of the mutuality between human and nature illustrate what modern environmental movements advocate.

In The Old Man and the Sea, Hemingway proposes his new idea about human's position in the whole living world when he relates the relationship between human being and the nature. According to his idea, "human being is not isolated from or superior to nature" (Worster,1985) and both human and non-human are members of the complicated ecological world. In his idea, human being and the great nature are closely related to and dependent upon each other and exist together harmoniously. In his work, Hemingway reminds us that we can only restore the harmonious relationship with the nature by pursuing simple material life and rich spiritual life. It is mean ingless for human beings to display their power or to realize themselves by any attempt to conquer the nature, because human being is powerless before the great nature and any attempt is bound to fail. "In the end human being will suffer severe, even destructive punishment from the nature no matter how much effort he has exerted to conquer it" (Wang,2003). Both human being and the great nature have their own borderline and activity circle. Hu man being has no right to invade other areas. To show respect to nature, preserve natural resources, admit the dignity of life and build a harmonious relationship with 
nature are essential for human being to survive in this planet. Otherwise, human being would, like Santiago, have to give back the big fish he captured to the great sea and suffer tremendous tortures and destructive blow.

\section{REFERENCES}

[1] Nelson, Barney. The Wild and the Domestic: Animal Representation, Eco-criticism, and Western American Literature. Reno: University of Nevada Press,2000.

[2] Mckusick, James C. Green Writing: Romanticism and Ecology. London: Macmillan Press Ltd, 2000.

[3] Hemin gway, Ernest. The Old Man and the Sea. Trans by Wu Lao. Shanghai: Shanghai Yiwen Press,2009.

[4] Simons, John. Animal Rights and the Politics of Literary Representation. New York: Palgrave, 2002.

[5] Worster, Donald. Nature's Economy: A History of Ecological Ideas[M]. Cambridge: Cambridge University Press, 1985.

[6] Wang Nuo. European and American Eco-literature. Beijing: Beijing University Press,2003. 